GHÂNCARAN: JURNAL PENDIDIKAN
BAHASA DAN SASTRA INDONESIA
http://ejournal.iainmadura.ac.id/ghancaran
E-ISSN : 2715-9132; P-ISSN: $2714-8955$
DOI 10.19105/ghancaran.v2i1.3188

\title{
SINEMA PASCANASIONAL: REPRESENTASI INDONESIA DALAM FILM-FILM GARETH EVANS
}

\author{
Rizky Abrian* \& Afwin Sulistiawati ${ }^{\star \star}$ \\ *BIPA Universitas Negeri Surabaya \\ **BIPA Universitas Negeri Surabaya
}

Alamat surel: abrianrizky@gmail.com*, afwinsw@gmail.com**

\begin{tabular}{ll}
\hline \hline & Abstract \\
\hline Keywords: & The emergence of Indonesian films lately is not only initiated by
\end{tabular}

films;

representations;

postnational
Indonesian directors, but also foreign directors. Gareth Evans who is a director from Wales managed to attract the attention of Indonesian film audiences with his films. The phenomenon of foreign directors who created Indonesian films to become representations in the world of international film is something that needs to be studied further.This research is descriptive qualitative because the data, words and sentences, are analyzed based on meaning relations. In analyzing the data, researchers used representation theory and the theory of postnational film, namely by searching for Indonesian representations of what is contained in the film and identifying the condition of postnational films in Evans's films. From the results of the analysis, it was found that there was a representation of Indonesia in films by Evans. The aspect of representation that appeared consisted of several aspects: aspects of the language of communication used in the film, aspects of settings that were raised as the background, aspects of characters based on the names of characters, backgrounds of figures, and the use of silat as a fighting style. It also found the condition of postnational films in Evans's films.

Abstrak:
Kemunculan film Indonesia pada masa kini tidak hanya diprakarsai
oleh sutradara Indonesia, tetapi juga sutradara dari luar negeri.
Gareth Evans merupakan sutradara dari Wales berhasil menarik
perhatian penonton film Indonesia dengan karyanya. Fenomena
sutradara luar negeri yang menciptakan film Indonesia hingga
menjadi representasi di dunia film internasional merupakan hal
yang perlu dikaji. Film nasional tidak hanya mencerminkan atau
mengungkap suatu esensi kebangsaan atau kebudayaan, tetapi
menunjukkan bahwa kebangsaan dan kebudayaan bagi film
nasional adalah unsur-unsur yang tersedia untuk dijelajahi.
Penelitian ini bersifat deskriptif kualitatif sebab data berupa kata-
kata dan kalimat yang dianalisis berdasarkan relasi makna.
Analisis data menggunakan teori representasi dan teori film
pascanasional, yaitu dengan mencari representasi Indonesia dan
mengidentifikasi kondisi film pascanasional dalam film-film Gareth
Evans. Hasil analisis dan interpretasi, ditemukan bahwa ada
representasi Indonesia dalam film-film garapan Gareth Evans.
Aspek representasi yang muncul, yakni aspek bahasa komunikasi
yang digunakan dalam film, aspek setting yang dimunculkan
sebagai latar film, aspek tokoh berdasarkan nama tokoh, latar
belakang tokoh, serta penggunaan silat sebagai gaya bertarung.
Selain itu, juga ditemukan kondisi film pascanasional dalam film-
film Gareth Evans.


Terkirim : 29 Maret 2020; $\quad$ Revisi: 21 Juli 2020; $\quad$ Diterima: 22 Juli 2020

(C)Ghâncaran: Jurnal Pendidikan Bahasa dan Sastra Indonesia

Tadris Bahasa Indonesia

Institut Agama Islam Negeri Madura, Indonesia

\section{PENDAHULUAN}

Film merupakan salah satu jenis hiburan yang diminati oleh masyarakat. Dalam perkembangannya film tidak sekadar menjadi hiburan yang kehadirannya hanya untuk konsumsi rekreasi, namun film juga berkembang menjadi bentuk media massa yang mempunyai peranan penting dalam sosiokultural, artistik, politik, dan dunia ilmiah. Pemanfaatan film sebagai media pembelajaran masyarakat dan penanaman nilai tertentu ini, dengan asumsi bahwa film memiliki kemampuan untuk mengantar pesan (McQuail, 2010).

Film merupakan media yang efektif untuk menyampaikan nilai-nilai dan filosofi kepada khalayak, serta dapat berperan sebagai sarana perenungan filosofis. Hal ini disebabkan karena film mampu menyingkapkan pergulatan batin eksistensial tersembunyi manusia dalam dunianya yang spesifik. Film adalah arsip sosial yang menangkap jiwa zaman (zeitgeist) masyarakat saat itu. Seorang pakar film, Siegfried Kracauer menyatakan bahwa pada umumnya dapat dilihat kalau teknik, isi cerita, dan perkembangan film suatu bangsa hanya dapat dipahami secara utuh dalam hubungannya dengan pola psikologis aktual bangsa itu. Artinya, perkembangan film Indonesia hanya dapat dipahami dengan baik jika perkembangan itu dilihat dalam hubungan dengan latar belakang perkembangan sosial budaya bangsa itu (Imanjaya $\mathrm{E}$, 2006).

Kemunculan film Indonesia pada masa kini tidak hanya diprakarsai oleh sutradara-sutradara Indonesia. Sutradara dari luar negeri turut pula mewarnai perkembangan produksi film Indonesia. Sebagai sutradara dari luar negeri, Gareth Evans yang merupakan sutradara dari Wales, berhasil menarik perhatian penonton film Indonesia dengan film-film garapannya. Tercatat, dari tiga film yang telah dibuatnya, semuanya berhasil mendapatkan penghargaan. Berdasarkan data yang didapat dari IMDB.com, film Merantau berhasil mendapatkan penghargaan dari Actionfest 2010 di Amerika. Film kedua, The Raid: Redemption berhasil memenangkan 9 penghargaan dan 9 nominasi di festival internasional, sedangkan film garapan terakhir Gareth Evans, The Raid: Berandal berhasil memenangkan 2 penghargaan dan 7 nominasi.

Sebagai sutradara yang menggarap film dalam genre film action, Gareth Evans membuat inovasi baru dengan menggunakan bela diri pencak silat sebagai gaya bertarung dalam film-filmnya. Sebenarnya, penggunaan pencak silat dalam film bukanlah hal baru. Di era orde baru pencak silat sudah digunakan sebagai gaya bertarung, namun hanya dalam film-film kolosal sehingga penggunaan bela diri pencak silat dalam film-film yang menggunakan setting masa kini merupakan hal yang belum pernah digunakan sebelumnya oleh sutradara-sutradara lain.

Fenomena Gareth Evans yang merupakan sutradara asing namun berhasil memperkenalkan film Indonesia di dunia film internasional merupakan hal yang perlu dikaji lebih lanjut. Keberhasilannya memperoleh penghargaan di festival film internasional menjadikan Indonesia lebih dikenal di dunia internasional. Representasi Indonesia dalam film-film Gareth Evans menjadi salah satu fokus perhatian untuk dikaji lebih lanjut. Selain itu, fenomena sutradara luar negeri yang menciptakan film Indonesia hingga menjadi representasi di dunia film internasional juga merupakan hal yang perlu dikaji lebih lanjut. Berbicara tentang film nasional, Seno Gumira Ajidarma menyatakan bahwa pengertian 'nasional' tak dapat dibatasi dalam hanya satu pengertian dan satu identitas yang terisolasi secara utuh, karena hubungan antara film nasional dan kebangsaan hanyalah suatu kemungkinan, bukan suatu esensi. Film nasional tidak mencerminkan atau mengungkap suatu 'esensi' kebangsaan atau kebudayaan, 
melainkan bahwa kebangsaan dan kebudayaan bagi film nasional adalah unsur-unsur yang tersedia untuk dijelajahi (Ajidarma, 2014).

Perubahan yang terjadi pada masyarakat posmodern, yang menyebabkan produksi film merupakan proses produksi kooperatif yang bisa dilakukan oleh pekerja lintas negara, merupakan fenomena yang menimbulkan persepsi baru, apakah hal tersebut bisa dikatakan film nasional atau hanyalah film yang merepresentasikan identitas nasional. Hal ini menjadi alasan kedua yang menjadikan penulis merasa perlu untuk mengkaji lebih lanjut tentang fenomena ini. Adapun rumusan masalah dari penelitian ini adalah (1) bagaimana representasi Indonesia yang terdapat dalam film-film karya Sutradara Gareth Evans dan (2) bagaimana kondisi film pascanasionalis dimunculkan dalam film-film karya Sutradara Gareth Evans.

\section{Film sebagai Media}

Film sebagai salah satu bentuk media massa yang mempunyai peranan penting dalam sosiokultural, artistik, politik, dan dunia ilmiah. Pemanfaatan film sebagai media pembelajaran masyarakat dan penanaman nilai tertentu ini diasumsikan bahwa film memiliki kemampuan untuk mengantar pesan (McQuail, 2010). Film telah berkembang, dari sekadar sarana hiburan menjadi media berkomunikasi, yang dapat mengejawantahkan maksud dan pesan dari para pembuat film. Termasuk dalam bagaimana cara mereka menggambarkan representasi negara-bangsa. Dalam memandang film sebagai media saat ini, perlu perspektif baru karena peran film saat ini telah berbeda dengan masa sebelumnya. Media, sebuah institusi yang memberikan sebuah konseptualitas tentang realita tidaklah berada di ruang hampa. Hal ini dikarenakan media sesungguhnya berada di tengah realitas sosial yang sarat dengan berbagai kepentingan-kepentingan pelaku di baliknya (Sobur, 2006). Dalam memandang film sebagai media, konstruksi media perlu dikritisi agar dapat melihat fenomena atau realitas secara berimbang. Maka dari itu diperlukan analisis tekstual dengan menempatkan film sebagai teks budaya.

Analisis tekstual merupakan salah satu kajian yang banyak dilakukan dalam media studies dan cultural studies. Analisis tekstual merupakan salah satu metodologi yang digunakan untuk mengupas, memaknai, sekaligus mendekonstruksi ideologi, nilainilai, atau kepentingan yang ada di balik suatu teks media ( $R$ Ida, 2011). Dalam analisis tekstual, teks dan budaya tidak dapat dipisahkan. Teks merupakan produksi dan konstruksi dari budaya, dan budaya merupakan koneksi untuk memberikan variasi ( $R$ Ida, 2011). Yang dimaksud teks dalam kajian media dan budaya adalah semua yang tertulis, gambar, film, video, foto, desain grafis, lirik lagu, dan lainnya yang menghasilkan makna ( $\mathrm{R}$ Ida, 2011). Dalam penelitian ini yang menjadi teks untuk diteliti adalah sinema, yaitu film Merantau, The Raid: Redemption, dan The Raid: Berandal.

Analisis wacana atau discourse analysis akan membuka kesadaran peneliti dalam level yang paling tinggi terhadap motivasi-motivasi yang tersembunyi pada satu sisi dan diri kita pada sisi yang lain (Ida, 2011). Dalam menganalisis sebuah wacana, kita perlu mengetahui terlebih dahulu apa yang dimaksud dengan wacana. Menurut Fairclough (Bardici, 2012), wacana adalah bahasa yang digunakan untuk merepresentasikan suatu praktik sosial, ditinjau dari sudut pandang tertentu. Sedangkan menurut konsep Foucault, wacana mengandung adanya kekuasaan di balik pernyataanpernyataan (Purbani W, 2005).

\section{Film sebagai Identitas Nasional}

Film sebagai identitas nasional di Indonesia berubah-ubah posisinya mengikuti sejarah perfilman di Indonesia. Sejarah mengenai perfilman Indonesia diawali pada tahun 1950. Usmar Ismail adalah tokoh utama dalam pendirian sinema nasional pada masa kemerdekaan. Bersama dengan beberapa koleganya Usmar Ismail mendirikan Perusahaan Film Nasional (Perfini). Dengan modal yang terbatas Perfini membuat film 
Indonesia pertama yang berjudul Darah dan Doa pada bulan Maret tahun 1950. Film Darah dan Doa merupakan film yang bercerita tentang revolusi fisik di Indonesia. Dalam orasinya, Seno Gumira menyatakan bahwa film Darah dan Doa ini sebagai film pertama yang secara resmi merupakan proyek ideologis nasionalisme, dan bukanlah suatu esensi Indonesia, melainkan konstruksi Indonesia (SG Ajidarma, 2014).

Orde baru menjadikan film sebagai media propaganda yang efektif dengan mendirikan institusi yang mengatur industri dan distribusi sinema. Pemerintah Orde Baru mendirikan Lembaga Perfilman Nasional (Lepfinas) pada tahun 1970. Lembaga ini kemudian mengalami inkorporasi lebih kuat oleh pemerintah, ketika pemerintah Orde Baru mengubahnya menjadi Dewan Film yang diketuai oleh Menteri Penerangan secara ex-offipcio (Junaedi, 1994). Fasisme Orde Baru semakin terlihat melalui film-film yang diproduksi selalu menampilkan epik kepahlawanan militer terutama ketika Presiden Soeharto masih aktif di militer. Film G-30-S/PKI merupakan ikon yang paling penting dalam mencitrakan sosok Soeharto sebagai pahlawan. Film pertama yang menokohkan Soeharto sebagai pahlawan adalah film Janur Kuning yang diproduksi pada tahun 1979 dengan biaya sekitar 385 juta Rupiah. Angka tersebut dianggap sebagai angka yang fantastis karena pada tahun tersebut biaya produksi sebuah film umumnya menghabiskan dana 200 juta Rupiah (Sen, 2009).

Memasuki era 1990-an dapat dikatakan sebagai era terpuruknya perfilman Indonesia. Hal ini disebabkan oleh maraknya sinetron-sinetron di televisi-televisi swasta. Pada saat yang hampir bersamaan, televisi swasta mengalami perkembangan yang cukup signifikan dengan memberikan bentuk tayangan baru bagi masyarakat yaitu sinetron. Pada tahun ini, bisa dikatakan bahwa perfilman Indonesia mengalami mati suri. Selanjutnya pada tahun 2000-an, kemunculan film Indonesia diawali dengan film Petualangan Sherina yang menarik perhatian peminat film Indonesia. Selanjutnya kemunculan film Ada Apa Dengan Cinta yang fenomenal menjadi tonggak bagi kemunculan film-film Indonesia selanjutnya. Bangkitnya film Indonesia juga berpengaruh pada industri film Indonesia yang menjadikan film sebagai komoditi di dunia hiburan.

Di balik kebangkitan industri film Indonesia, terdapat beberapa oknum yang menggunakan komodifikasi seksual dalam film horor sebagai sarana mendapatkan keuntungan. Selain itu komodifikasi religi juga turut mewarnai kebangkitan film Indonesia di era reformasi. Meski begitu, juga terdapat beberapa film berkualitas dan memenangkan penghargaan nasional dan internasional seperti Tanda Tanya, Opera Jawa, dan The Raid. Mcquaill mengungkapkan bahwa film sebagai salah satu media massa mengandung unsur-unsur ideologi dan propaganda yang terselubung dan tersirat (McQuail, 2010). Film memiliki kemampuan untuk menarik perhatian orang serta mampu mengantarkan pesan secara unik. Film merupakan representasi dari kehidupan masyarakat. Representasi merupakan pemaknaan konsep pikiran seseorang melalui bahasa (Hall, 1997). Menurut Hall, representasi merupakan pemaknaan konsep pikiran seseorang melalui bahasa. Hall menyatakan bahwa representasi yang menghubungkan konsep-konsep dengan bahasa memungkinkan kita untuk memilah objek-objek, orang, ataupun kejadian 'nyata' dengan dunia imajinatif dari objek-objek, orang, atau kejadian fiksi.

Sehubungan dengan hal tersebut, (Hall, 1997) mengungkapkan pendekatan untuk menjelaskan bagaimana representasi makna bahasa. Pertama yaitu reflective approach, makna dipandang seperti cermin yang merefleksikan kenyataan. Namun Graeme Turner dalam Irawanto menyanggah pandangan perspektif film yang disebut sebagai refleksi masyarakat. Film bukan hanya sekadar refleksi masyarakat, tapi juga merupakan representasi realitas masyarakat melalui kode-kode, kesepakatan, mitos, dan ideologi dari suatu budaya (Irawanto, 1999). Kedua, intentional approach, yang memandang kata-kata sebagai sesuatu yang bermakna apabila komunikator bertujuan untuk membuatnya bermakna. Yang ketiga adalah constructionist approach yaitu 
beranggapan bahwa sesuatu sebenarnya tidak bermakna, manusia yang mengonstruksi makna menggunakan konsep dan tanda berdasarkan pandangan constructionist approach (Hall, 1997). Konstruksi makna dilakukan oleh individu. Demikian pula yang terjadi di dalam film, realitas dalam film dikonstruksi oleh masyarakatnya sendiri. Konstruksi realitas dalam film ini menciptakan stereotip tertentu terhadap kelompok masyarakat tertentu.

\section{Film Pascanasional}

Istilah pascanasional sendiri menurut Seno Gumira Ajidarma tersadur dari post, yang berasal dari kata posmodernisme, ketika kata modern sendiri berasal dari modus yang berarti 'cara' (SG Ajidarma, 2014). Kata pasca bermakna perkembangan dan transformasi tertentu yang berlangsung dalam rangka modernitas sehingga 'pascanasional' sebagai kemungkinan sebetulnya sudah terkandung dalam 'nasional' yang oleh situasi global menjadi berbagai dimensi nan tumpang tindih. Menurut penyataan (SG Ajidarma, 2014) 'film nasional' telah berada dalam kondisi pascanasional, yang tak dapat diwakili hanya oleh pengertiannya yang paling klasik, seperti: film Indonesia dibikin oleh manusia ber-KTP Indonesia, bermodal Indonesia, tentang Indonesia, bermain di Indonesia, berbahasa Indonesia, dan lain sebagainya, yang disebut pertimbangan teritorial.

Pernyataan Ajidarma tentang pertimbangan teritorial merupakan penjelasan bahwa untuk mencapai film sebagai identitas nasional hanyalah persyaratan formal dan seolah-olah sebagai jaminan absolut bahwa apabila sebuah film ingin menjadi film nasional maka harus memenuhi syarat pertimbangan teritorial tersebut. Pertimbangan teritorial ini sudah tidak bisa dijadikan faktor utama tentang identitas nasional sebuah film, terdapat faktor lain yang menjelaskan bagaimana posisi film sebagai identitas nasional, yaitu pertimbangan fungsional dan pertimbangan relasional. Menurut Ajidarma bahwa film dengan identitas yang baru ini, betapapun kontemporer dan revolusioner pemberontakannya, secara tekstual tetap dapat dipertanggungjawabkan hubungannya dengan kebangsaan dan kebudayaan Indonesia (SG Ajidarma, 2014).

Film nasional bisa diterima (akal) hanya sebagai hubungan, bukan esensi, yang keberadaannya tergantung kepada perbandingan dengan film hollywood maupun film nasional (negara-bangsa) lain. Pertimbangan relasional ini, dengan begitu menggugat dikotomi nasional-transnasional. Salah satu contoh yang dijelaskan oleh Ajidarma adalah film-film karya Garin Nugroho, yang meski (hanya) beredar dalam berbagai festival internasional dan dibiayai dana non-Indonesia, secara tekstual terhubungkan dengan kuat kepada akar budaya, yakni dalam kenyataanya non-hollywood, sehingga mendapatkan fungsinya sebagai representasi negara-bangsa yang disebut Republik Indonesia (Adjidarma, 2014).

\section{METODE}

Penelitian ini bersifat deskriptif kualitatif sebab data yang disajikan dalam penelitian ini berupa kata bukan angka. Penelitian ini menyajikan data berupa kata-kata dan kalimat yang dianalisis berdasarkan relasi maknanya. Sumber data dalam penelitian ini adalah paradigma-paradigma berupa dialog, perilaku, kerja kamera, serta elemenelemen lain yang menyusun sebuah film, yang membentuk sintagma-sintagma berupa representasi di dalam film-film karya Gareth Evans. Data primer penelitian ini berasal dari fail film Merantau, The Raid: Redemption, dan The Raid: Berandal.

Sedangkan data sekundernya berupa studi kepustakaan tentang film sebagai representasi. Data dilakukan dengan cara mengamati, menganalisis, dan menginterpretasi paradigma-paradigma yang terdapat di dalam film Merantau, The Raid: Redemption, dan The Raid: Berandal, untuk menemukan sintagma berupa representasi Indonesia dalam film-film karya Gareth Evans. Untuk menganalisis data-data, peneliti 
menggunakan metode analisis wacana, yaitu dengan mencari wacana apa saja yang terkandung dalam Merantau, The Raid: Redemption, dan The Raid: Berandal yang mengandung praktik representasi tentang Indonesia.

\section{HASIL DAN PEMBAHASAN}

Gareth Evans merupakan Sutradara asal Wales, Britania Raya. Gareth Evans adalah alumni jurusan film di Universitas Cardiff dan penulisan skenario di Universitas Glamorgan. Film-film yang sudah dihasilkannya antara lain Mystic Arts of Indonesia: Pencak Silat (2008), Merantau (2009), The Raid: Redemption (2012), dan terakhir The Raid: Berandal (2014). Film merantau merupakan film Indonesia yang bercerita tentang pemuda minangkabau bernama Yudha yang merantau ke Jakarta untuk bekerja, namun di tengah perjalanan mencari pekerjaan di Jakarta dia bertemu dengan Putri yang menjadi korban sindikat perdagangan manusia. Yudha yang ingin menyelamatkan Putri harus melawan sindikat, dan melawan jaringan penjahat yang memburunya. Film ini merupakan film bioskop Indonesia pertama garapan Gareth Evans pada tahun 2009.

Film The Raid: Redemption adalah film yang berkisah tentang operasi polisi yang menggerebek gembong narkoba di dalam apartemen yang merupakan sarang penjahat. Polisi-polisi tersebut harus menghadapi berbagai macam penjahat yang dipimpin Tama yang telah bersiap untuk menghentikan mereka. Film ini merupakan sekuel pertama dari The Raid yang dirilis pada tahun 2011. The Raid: Berandal merupakan film ketiga garapan Gareth Evans yang selesai dirilis pada tahun 2014. Film ini merupakan sekuel kedua dari film The Raid: Redemption. Film ini bercerita tentang kelanjutan kisah Rama yang harus menyamar dan masuk ke dalam lingkaran geng terbesar di Jakarta untuk membongkar sindikat serta membalaskan kematian kakaknya. Di film ini Rama harus terlibat dalam peperangan geng yang disebabkan oleh Ucok yang ingin menguasai kekuasaan ayahnya, yang merupakan pemimpin geng sesegera mungkin.

\section{Representasi Indonesia dalam Film-film Gareth Evans}

Representasi Indonesia dalam Film-film Gareth Evans ditunjukkan dalam berbagai aspek yang bisa diketahui oleh audien bahwa aspek-aspek tersebut merupakan hal-hal yang mewakili Indonesia. Aspek-aspek dalam film yang dimunculkan adalah yang pertama, mengandung unsur reflective approach, makna dipandang seperti cermin, yang merefleksikan kenyataan. Yang kedua adalah intentional approach, yang memandang kata-kata sebagai sesuatu yang bermakna apabila komunikator bertujuan untuk membuatnya bermakna. Yang ketiga adalah constructionist approach yaitu beranggapan bahwa sesuatu sebenarnya tidak bermakna, manusia yang mengkonstruksi makna menggunakan konsep dan tanda (Hall, 1997).

Sebagai film Indonesia, aspek pertama dalam ketiga film Gareth Evans adalah adanya penggunaan bahasa Indonesia sebagai bahasa komunikasi dalam film. Hampir di setiap film sebagian besar menggunakan bahasa Indonesia. Hanya ada sedikit bagian dalam film yang menggunakan bahasa asing, yaitu dalam film Merantau ketika dialog antara ketua sindikat perdagangan manusia yang berasal dari Eropa, lalu dalam film The Raid: Berandal dalam dialog antara Bangun, ketua geng Jakarta berbicara kepada Goto, ketua geng Jepang dalam bahasa Jepang. Sedangkan dalam film The Raid: Redemption keseluruhan bahasa yang digunakan adalah bahasa Indonesia. Pemakaian bahasa asing tetap ada namun jumlahnya yang sangat sedikit tidak terlalu mempengaruhi komunikasi dalam ketiga film ini. Untuk pemutaran internasional, film ini tetap menggunakan bahasa Indonesia sebagai bahasa komunikasi dalam film, bagi penonton yang tidak menguasai bahasa Indonesia, subtitle dengan bahasa sesuai dengan negara masing-masing dimunculkan untuk memudahkan pemahaman audien terhadap cerita dalam film. 
Aspek kedua yang menunjukkan representasi Indonesia dalam film adalah setting. Dalam film Merantau, setting yang dimunculkan adalah lokasi-lokasi yang berada di Indonesia. Adegan pembuka Merantau diawali dengan latar Ngarai Sianok yang merupakan salah satu lokasi yang berada di Indonesia, tepatnya adalah Kabubaten Agam, Sumatera Barat.

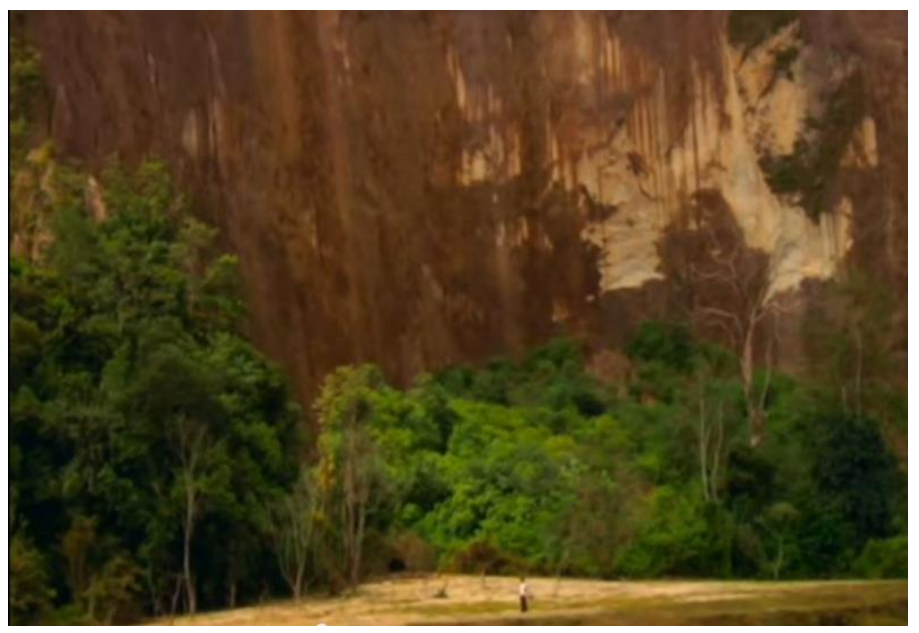

Gambar 1. Ngarai sianok dalam film Merantau

Ngarai Sianok merupakan ngarai 'lembah yang curam' yang terdapat di Bukittinggi, Sumatera Barat. Ngarai Sianok merupakan objek wisata yang memiliki pemandangan yang indah. Bagi sebagian orang Indonesia, gambaran Ngarai Sianok yang dimunculkan dalam film merupakan refleksi bahwa kehidupan dalam film mengacu dari kehidupan yang ada di Indonesia. Setting kedua dalam film merantau adalah penggunaan baju endong sapatagak. Baju ini merupakan seragam yang digunakan dalam berlatih oleh pendekar silat Minangkabau. Pakaian yang khas ini juga menunjukkan bahwa setting dalam film sangat fokus dan jelas dalam menunjukkan representasi Indonesia.

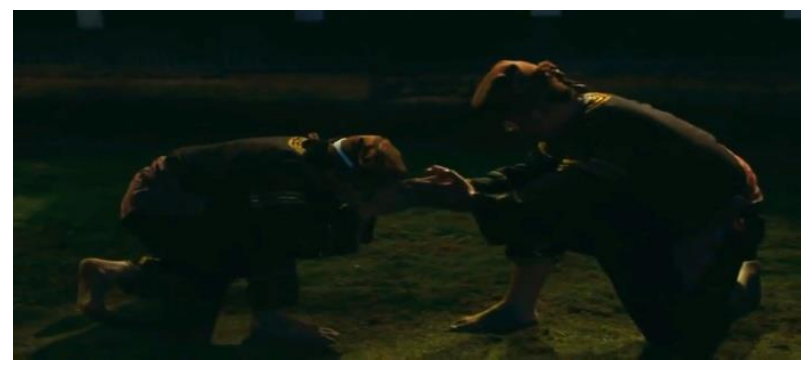

Gambar 2. Baju endong sapatagak dalam film Merantau

Setting selanjutnya dalam film Merantau tidak terlalu menunjukkan secara langsung bahwa setting tersebut berada di Indonesia karena dalam adegan selanjutnya tidak dimunculkan setting-setting ikonik ataupun landmark yang bisa merefleksikan audien bahwa setting film tersebut berada di Jakarta. Dalam film The Raid: Redemption, tidak dimunculkan secara visual bahwa setting cerita film berada di Indonesia, film ini lebih banyak mengambil lokasi dalam ruangan di sebagian besar adegannya. Meski begitu,penyebutan secara tidak langsung serta penggunaan mobil polisi yang mirip dengan kepolisian Indonesia cukup berhasil menunjukkan kepada audien bahwa setting film tersebut berada di Indonesia.

Dalam film The Raid: Berandal, terdapat beberapa adegan yang menampilkan secara visual menunjukkan lokasi Indonesia dalam film. Adegan pertama adalah adegan kejar-kejaran mobil yang menggunakan terminal busway sebagai lokasi tabrakan. 
Adegan tabrakan di terminal busway ini menunjukkan adanya setting Indonesia dalam film. Selain itu, penggunaan lokasi kota tua Jakarta dalam film muncul di beberapa adegan. Kota tua Jakarta merupakan ikon terkenal sebagai lokasi wisata di DKI Jakarta. Kota tua Jakarta atau bisa disebut dengan Batavia Lama merupakan landmark kota Jakarta yang menampilkan sisi kota Jakarta pada masa lampau. Gedung-gedung dengan gaya arsitektur lama yang merupakan karakter khas kota tua Jakarta memunculkan representasi Indonesia dalam film tersebut.

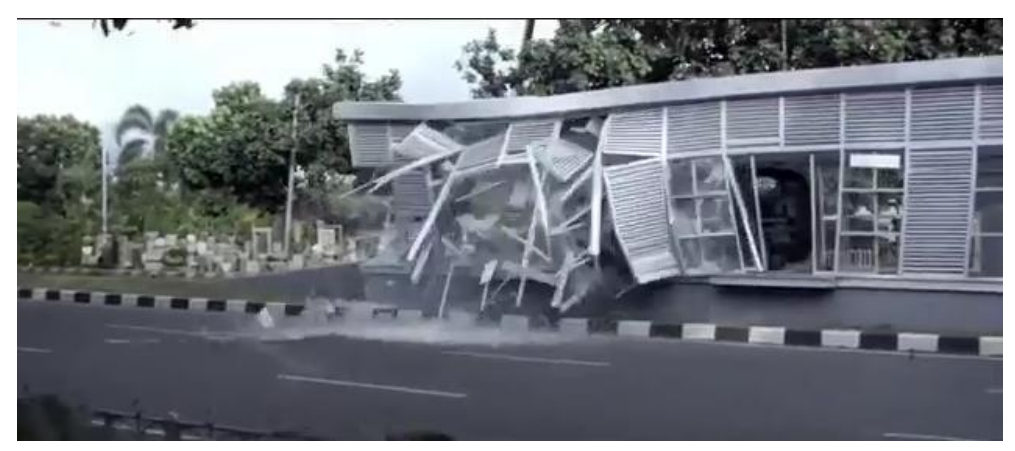

Gambar 3. Terminal busway dalam film The Raid : Berandal

Hal terakhir yang menunjukkan representasi Indonesia dalam The Raid: Berandal adalah adanya pertunjukkan reog sebagai latar salah satu adegan dalam film ini. Adegan pertunjukkan reog ini muncul pada adegan pertarungan antargeng. Dalam adegan ditunjukkan adanya pertunjukkan reog yang disaksikan oleh orang banyak, yang kemudian bubar karena ketakutan oleh adegan perang antargeng dalam film.

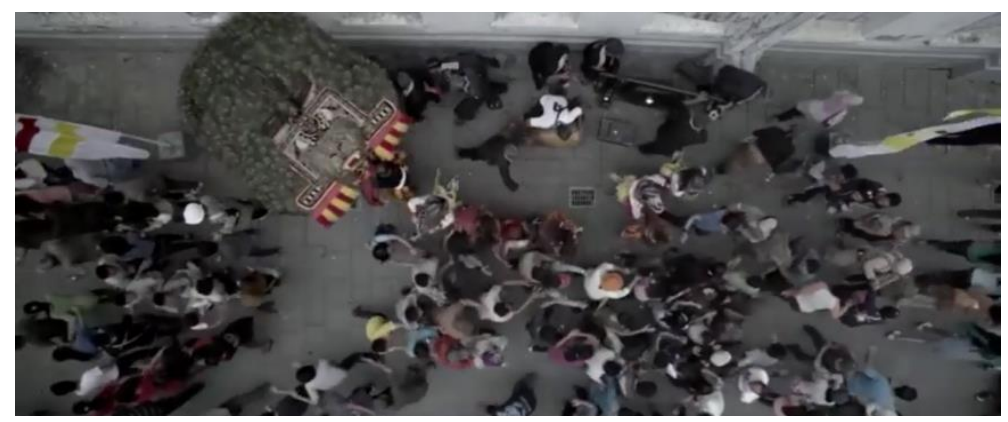

Gambar 4. Reog dalam film The Raid : Berandal

Aspek ketiga dalam film yang menunjukkan representasi Indonesia adalah penggunaan tokoh serta nama tokoh yang digunakan dalam film. Dalam film Merantau, tokoh Yudha merupakan nama Indonesia yang berasal dari bahasa Jawa Kuna yang berarti perang. Selain itu posisi Yudha sebagai tokoh utama memiliki latar belakang suku Minangkabau yang merupakan salah satu suku di Sumatera Barat, Indonesia. Penggunaan nama tokoh lain seperti Adit, Yayan, Astri, dan Wulan sebagai nama tokoh lain dalam film ini juga membantu audien dalam memahami bahwa konstruksi cerita dalam film ini merupakan cerita yang berada di Indonesia.

Sama dengan film sebelumnya, film The Raid: Redemption juga memunculkan representasi Indonesia melalui penggunaan nama-nama yang identik dengan nama Indonesia. Dalam film ini, tokoh-tokohnya sebagian besar menggunakan nama yang khas Indonesia, nama seperti Rama, Andi, Wahyu, Jaka, Tama, dan Bowo. Selain itu, juga terdapat tokoh-tokoh yang mengingatkan audien tentang Indonesia yaitu ketika adegan pertarungan antara polisi melawan geng yang identik dengan masyarakat Indonesia Timur. Dalam adegan tersebut terdapat dialog yang terjadi ketika ketua geng Machete gagal menemukan polisi yang bersembunyi. Ketua geng tersebut berbicara dengan dialek yang khas dengan Indonesia Timur. 
"Kau stop tipu-tipu. Saya trada waktu buat kau tipu. Kalau saya muak, saya menggila!" (The Raid: Redemption).

Dalam adegan ini, dialog diperankan oleh ketua geng yang dari tampilan visualnya khas orang Indonesia Timur, berkulit gelap, berwajah tegas, dan aksen bicara yang cepat. Konstruksi dalam film seperti ini sangat membantu audien Indonesia dalam memahami bahwa adegan tersebut dilakukan oleh tokoh dari Indonesia Timur. Dalam film ketiga, The Raid: Berandal, penggunaan nama tokoh masih tetap dengan penggunaan nama yang biasa digunakan di Indonesia. Tokoh dengan nama Rama masih tetap menjadi tokoh utama, disertai tokoh-tokoh baru seperti Bangun, Ucok, Eka, Bejo, dan Prakoso. Nama yang paling khas menunjukkan representasi Indonesia adalah penggunaan nama Ucok yang merupakan nama khas dari suku Batak. Nama Ucok di sini digunakan sebagai nama tokoh yang berperan sebagai anak dari ketua gangster terbesar dalam film tersebut.

Selain penggunaan nama dalam tokoh-tokoh film The Raid: Berandal, terdapat salah satu bagian adegan dengan dialog yang mengisyaratkan adanya nasionalisme secara tidak langsung yang dilakukan oleh tokoh Ucok ini. Dalam adegan tersebut ditunjukkan bagaimana Ucok yang tidak terima dengan ayahnya yang memohon maaf kepada ketua geng Jepang dengan menggunakan bahasa Jepang.

"Bapak minta maaf kepada mereka! Dalam bahasa mereka! Di atas tanah kita!!!" (The Raid 2: Berandal)

Kutipan dialog di atas juga menunjukkan sikap nasionalisme Ucok setelah melihat permintaan maaf yang dilakukan ayahnya kepada orang Jepang. Meskipun dialog ini tidak sepenuhnya menunjukkan representasi karakter Indonesia, namun dari dialog tersebut dapat diketahui bahwa Ucok merupakan orang Indonesia yang memiliki rasa nasionalisme tinggi.

Aspek terakhir yang menunjukkan representasi Indonesia dalam film-film Gareth Evans adalah penggunaan silat sebagai gaya bertarung. Tokoh-tokoh utama dalam filmfilm Gareth Evans juga tidak berlatar belakang dunia film, namun berasal dari latar belakang perguruan pencak silat. Iko Uwais sebagai pemeran utama dalam film-film Gareth Evans merupakan atlet pencak silat yang memperoleh berbagai prestasi di dunia pencak silat, Iko Uwais terhitung mendapat penghargaan Juara III, Kejuaraan Daerah Antarperguruan DKI Jakarta tahun 2003, dan sebagai Penampilan Terbaik Kategori Dewasa Tunggal pada Festival Pencak Silat Cibubur 2005.

Selain itu tokoh penting lain yaitu Yayan Ruhiyan, yang juga menjadi tokoh penting ke dalam tiga film merupakan pendekar pencak silat dan juga pelatih silat PSTD (Pencak Silat Tenaga Dasar). Selain itu Yayan Ruhiyan juga aktif di Padepokan Silat TMII. Pemilihan tokoh yang berasal dari latar belakang bela diri silat juga mempengaruhi gaya bertarung dalam film-film Gareth Evans. Film garapan Gareth Evans memperlihatkan kentalnya gaya bertarung silat yang khas sehingga terlihat berbeda apabila dibandingkan gaya bertarung film-film lain yang menggunakan bela diri kungfu, MMA (Mixed Martial Arts), atau gaya bertarung jalanan.

Silat sendiri merupakan pencak silat yang cukup dikenal di Indonesia, selain dengan keberadaan silat yang sudah sejak lama dikenal, bermacam-macam aliran silat juga mewarnai perkembangan silat di Indonesia. Dalam film Gareth Evans, terdapat beberapa gaya aliran silat yang dimunculkan, dalam film Merantau aliran silat silek minang merupakan gaya bertarung yang dimunculkan oleh tokoh utama, lalu dalam film The Raid: Berandal gaya silat panglipur ditunjukkan oleh tokoh penjahat dalam film. Keragaman aliran silat yang dimunculkan juga menunjukkan bahwa dari beberapa tokoh dalam film Gareth Evans, aliran silat para tokoh pun berasal dari perguruan yang berbeda-beda. Iko Uwais berasal dari perguruan silat Betawi, sedangkan Yayan 
Ruhiyan berasal dari perguruan silat PSTD, sedangkan Cecep Arif dalam film The Raid: Berandal merupakan pendekar yang berasal dari pencak silat Panglipur, dan Very Tri Yulisman berasal dari perguruan silat Tiga Berantai.

\section{Film pascanasionalis melalui Film-film Gareth Evans}

Mengacu pada pendapat (SG Ajidarma, 2014) yang menyatakan bahwa 'film nasional' telah berada dalam kondisi pascanasional, yang tak dapat diwakili hanya oleh pengertiannya yang paling klasik, seperti: film Indonesia dibikin oleh manusia ber-KTP Indonesia, bermodal Indonesia, tentang Indonesia, bermain di Indonesia, berbahasa Indonesia dan lain sebagainya, yang disebut pertimbangan teritorial. Terdapat bukti bahwa film nasional saat ini telah bergeser posisinya menjadi film pascanasional.

Sebagai kesatuan produksi film, film Gareth Evans merupakan film yang proses produksinya melibatkan peran lintas negara. Sebagai sutradara, Gareth Evans merupakan warga negara Wales, yang didukung oleh Sony Pictures Classic dari Amerika dengan membeli hak tayang dari film The Raid: Redemption. Sedangkan dalam penggunaan aktor, ada yang berasal dari Indonesia, Eropa (Merantau), dan Jepang (The Raid: Berandal). Sedangkan Mike Shinoda yang merupakan personil band internasional Linkin Park menjadi anggota dari sisi musik dalam film ini.

Kondisi produksi film yang menggunakan anggota dari berbagai negara menunjukkan adanya peran lintas negara yang membentuk film ini. Dari sisi teritorial, film ini tidak bisa disebut sebagai film nasional, tetapi film multinasional. Namun, dalam sisi esensi film, narasi besar apa yang paling kuat disampaikan dalam film kepada audien menunjukkan adanya indikasi bahwa film ini merupakan film nasional. (SG Ajidarma, 2014) menyatakan bahwa film dengan identitas yang baru ini, betapapun kontemporer dan revolusioner pemberontakannya, secara tekstual tetap dapat dipertanggungjawabkan hubungannya dengan kebangsaan dan kebudayaan Indonesia. Film-film Gareth Evans memunculkan banyak hal yang disampaikan melalui film, namun terdapat satu hal dominan dan terus menerus muncul sebagai narasi utama, yakni filmfilm Gareth Evans ingin menunjukkan budaya pecak silat sebagai pendobrak konvensi gaya bertarung dalam genre film action pada umumnya.

Dalam film action sebelumnya, sering menjadi konvensi bahwa sebagian besar gaya bertarung yang digunakan adalah gaya bertarung MMA, tinju, kungfu, dan gaya bertarung lain yang bukan pencak silat. Selama ini pencak silat hanya diposisikan sebagai seni bela diri yang ditampilkan secara langsung, adapun pemunculan pencak silat dalam film hanya terjadi di film-film kolosal yang menggunakan latar waktu masa lampau, tidak pada film-film action dengan latar waktu masa sekarang. Revolusi ini menjadi penting mengingat dengan menggunakan pencak silat dalam film, terjadi beberapa respon dalam dunia film bergenre action tersebut. Penghargaan dan nominasi yang diperoleh merupakan salah satu bukti bahwa penggunaan pencak silat sebagai gaya bertarung dalam film merupakan revolusi yang penting dalam perkembangan dunia film khususnya genre action. Revolusi ini diketahui internasional diawali oleh pencak silat Indonesia sehingga dengan pertimbangan relasional, esensi dalam film-film Gareth Evans telah memenuhi tugasnya sebagai film nasional yang merepresentasikan Indonesia.

\section{Licentia Poetica: Salju dan Kereta Api Cepat di Jakarta}

Terdapat beberapa hal yang menarik untuk dikaji mengenai kelogisan dunia dalam film-film Gareth Evans, terutama dalam film The Raid: Berandal. Beberapa adegan yang menggunakan setting yang bias menimbulkan banyak persepsi atas kelogisan semesta yang diciptakan sutradara, yang efeknya bisa mempengaruhi representasi Indonesia dalam film tersebut. Kemunculan kereta api cepat dalam film The Raid: Berandal merupakan salah satu contoh bagaimana biasnya penentuan setting 
bisa berpengaruh dalam representasi Indonesia dan juga esensinya sebagai film nasional. Perlu diketahui bahwa sampai saat film itu ditayangkan, di Indonesia belum ada kereta api cepat, namun dalam salah satu adegan pertarungan di film tersebut berada di kereta api cepat. Hal ini bisa menimbulkan kebimbangan audien tentang posisi Indonesia dalam film tersebut. Keraguan akan muncul di pikiran audien apabila menemukan hal yang tidak sesuai dengan kenyataan audien atas pengetahuannya tentang Indonesia.

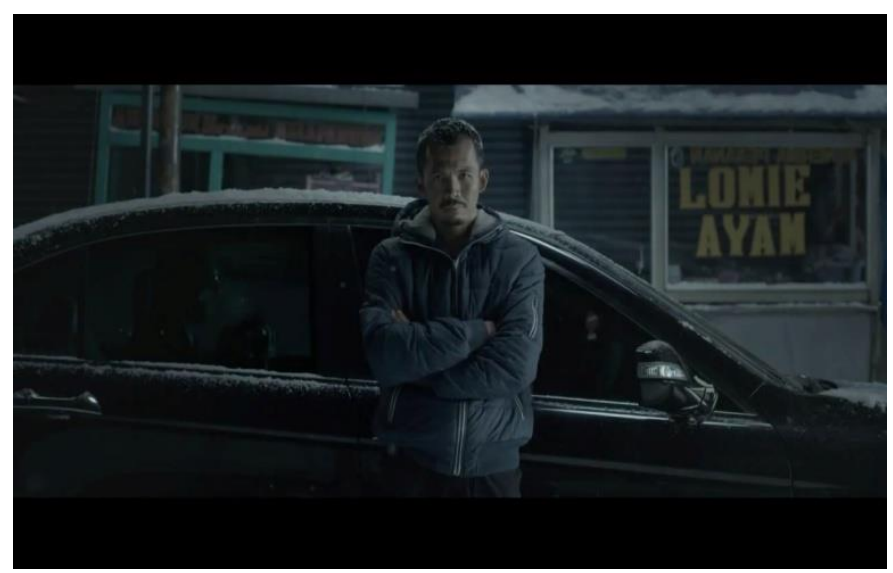

Gambar 5. Salju di Jakarta dalam film The Raid: Berandal

Kemunculan kedua adalah adanya salju di Jakarta. Dalam film The Raid: Berandal, salju di Jakarta ini muncul dalam adegan Prakoso ketika dibunuh oleh Assasins. Latar luar ruangan dengan hujan salju ini sangat mengganggu realitas audien ketika salju ini dimunculkan dengan visual gerobak makanan lomie Jakarta. Seperti diketahui bahwa Jakarta merupakan kota dengan iklim panas sehingga tidak mungkin terjadi hujan salju seperti yang terlihat dalam film.

Pertimbangan nuansa mungkin menjadi alasan mengapa terjadi ketidaksesuaian antara setting dalam film dengan realitas di kehidupan nyata. Salju yang dimunculkan bisa jadi digunakan untuk menambah efek dramatis kematian Prakoso. Efek darah yang keluar dalam kematian Prakoso menjadi lebih terlihat ketika salju menjadi latar belakang darah tersebut. Selain itu salju juga menimbulkan nuansa dingin dan beku yang sesuai dengan kematian Prakoso. Hal ini merupakan pertimbangan licentia poetica, yang biasanya diterapkan dalam puisi untuk pertimbangan mempertahankan atau membentuk suasana yang lebih estetis dalam karya seni tersebut.

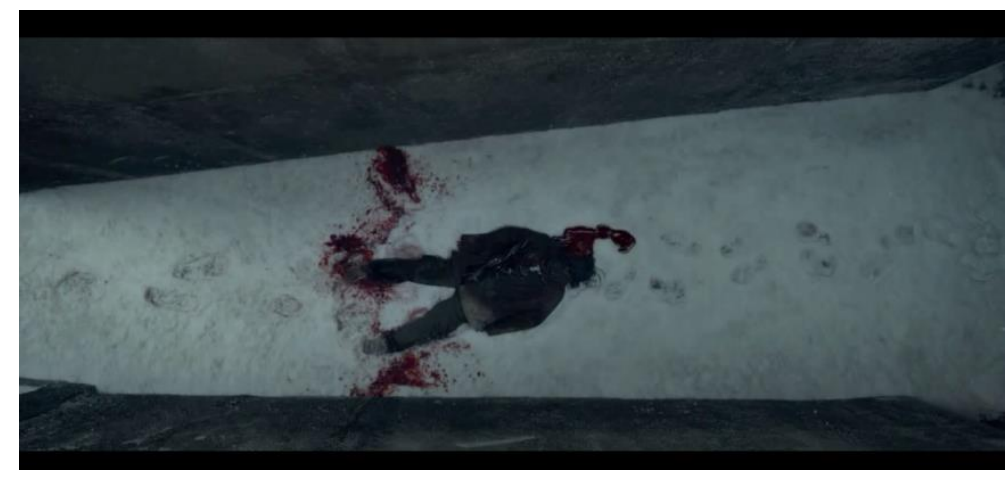

Gambar 6. Adegan kematian Prakoso di The Raid: Berandal

Meski begitu, licentia poetica dalam film tersebut merupakan kritik tersendiri terhadap posisinya sebagai film nasional, apakah pertimbangan efek nuansa cerita yang dibangun dipertahankan untuk memberi efek psikologis dalam film ataukah kelogisan 
setting yang bisa menjaga realitas pikiran audien sehingga tidak merasa ragu tentang representasi Indonesia dalam film ini. Namun demikian, licentia poetica tetap menjadi suatu kebebasan pembuat film terlepas dari alasan pemunculan hal-hal yang dianggap kurang logis bagi realita aslinya.

\section{SIMPULAN}

Berdasarkan analisis yang dilakukan terhadap objek, ditemukan adanya representasi Indonesia dalam film-film karya Gareth Evans. Aspek representasi yang muncul terdiri atas beberapa aspek, yakni aspek bahasa komunikasi yang digunakan dalam film, aspek setting yang dimunculkan sebagai latar film, aspek tokoh berdasarkan nama tokoh, latar belakang tokoh, serta penggunaan silat sebagai gaya bertarung dalam film-film karya Gareth Evans.

Temuan kedua adalah adanya kondisi pascanasional yang terjadi dalam film-film Gareth Evans. Kondisi ini diketahui dari anggota yang terlibat dalam proses produksi film ini melibatkan peran dari lintas negara. Meskipun demikian, peran multinasional dalam produksi film ini tidak terlalu mengganggu esensi film ini sebagai representasi film nasional Indonesia di dunia internasional. Beberapa aspek menjadi kajian kritis dalam analisis. Hal kritis yang ditemui adalah beberapa pemilihan setting yang berhubungan dengan licentia poetica yang tanpa memperhatikan kelogisan realitas yang dibangun dalam film sehingga mempengaruhi representasi Indonesia dalam film itu sendiri.

\section{DAFTAR RUJUKAN}

Ajidarma, SG. (2014). Film Indonesia dan Identitas Nasional dalam Kondisi Pascanasional. Film Indonesia. or. Id.

Bardici, M. (2012). A discourse analysis of the media representation of social media for social change-The case of Egyptian revolution and political change. https://muep.mau.se/handle/2043/14121

Hall, S. (1997). Representation: Cultural Representations and Signifying Practices Google Books. Sage, 2. https://books.google.co.id/books?hl=en\&lr=\&id=VsBdyhM9JEC\&oi=fnd\&pg=PA2\&dq=Hall,+S.+(1997).+REPRESENTATION:+Cultural +Representative+Signifying+Practices.+SAGE,+11.\&ots=GuCH4Acdxy\&sig=zYSbC sEnJ7YfiSLTjegE1aFhtBA\&redir_esc $=y \# v=0$ nepage\&q\&f=false

Ida, R. (2011). Metode Penelitian Kajian Media dan Budaya. Surabaya: AUP.

Imanjaya E. (2006). A to Z About Indonesian Film. Mizan.

https://scholar.google.com/scholar?hl=en\&as_sdt=0\%2C5\&q=A+to+Z+About+Indon esian+Film\&btnG=

Irawanto, B. (1999). Film, Idology, dan Militer. Yogyakarta: Media Pressindo.

Junaedi, N. (1994). Bisnis Film di Indonesia: Studi Deskriptif tentang Proses Komunikasi

Film dalam Konteks Dominasi Film Amerika di Indonesia. FISIPOL UGM, 47.

McQuail, D. (2010). Mass Communication Theory. London: Sage Publications.

Purbani W. (2005). ANALISIS WACANA/DISCOURSE ANALYSIS . Paper LokakaryaUBAYA, Surabaya.

Sen, K. (2009). Kuasa dalam Sinema: Negara, Masyarakat, dan Sinema Orde Baru. Yogyakarta: Ombak.

Sobur, A. (2006). Analisis Teks Media Suatu Pengantar. Remaja Rosdakarya 